\title{
Striking Report: The Creation, Enactment, and Application of the Three Strikes Law and An Appeal for California Voters to Amend It Forrest Lee Jones *
}

$\mathrm{T}$ his striking report, ${ }^{1}$ which draws heavily on the research of sociologist and professor Joshua Page (2011) of the University of Minnesota, critically examines the California Three Strikes Law, the events that led to its creation and its enactment, and the repercussions of its passage. The law is designed to incarcerate violent and nonviolent repeat offenders for long periods of time. Political considerations and social retribution are among the motivations that led conservative lawmakers' to pursue this measure targeting repeat offenders.

The Three Strikes Law surfaced “in the 1990's during a period of widespread decline of public support in legal and political authorities. Multiple studies demonstrated increasing scepticism and lack of confidence" in liberal judges, juries, and politicians' ability to lock away repeat offenders (Tyler and Boeckman, 1997). The law was a repudiation of the liberal judicial policies of the 1960's, 1970's, and 1980's by Three Strikes author Mike Reynolds and conservative groups, such as the California Correctional Peace Officers Association (CCPOA) and victim rights groups. The law takes discretionary authority away from these so-called liberal officials and gives it to prosecutors, whose job it is to defend victims, effectively stripping judges of their power by automatically mandating them to give life sentences to repeat offenders. These groups praised reducing judicial power, and increased prosecutorial discretion. Page (2011, p. 184) explains the union's approach:

For the CCPOA and its allies, Three Strikes was a victory over "liberal" policy makers who, before the 1990's spurned 'tough' approaches to crime and control, and in the words of the union, made incarceration in California 'the Ultimate Welfare Program'. Reflecting on 1994 and the Three Strikes, the CCPOA wrote in 1995, 'many of us would argue that California has finally come to its senses and is prioritizing crime fighting the way it's been ignored throughout most of the 60's and 70's and halfway through the 80 's'. The union added, 'true reform is happening presently which is to repeal the liberal policies of the 60's and 70's and get tough with the criminal element'. 
Mike Reynolds, an outspoken proponent of Three Strikes, states, "It is the story of one family's heartbreak of behind-the-scenes political manoeuvring by soft-on-crime, liberal politicians in an effect to eviscerate the law, and it's the story of the ultimate victory by a majority of Californians who, in a reversal of decades of citizen neglect, defied the crime 'experts and voted for common sense and justice" (Page, 2011, p. 134).

Reynolds and the CCPOA demonstrate their attitudes toward liberal policy makers and criminals. Instead of supporting rehabilitative policies that integrate convicts back into society, such as self-help, educational and vocational programs that protect public safety, they support punitive measures, like the Three Strikes Law, which hardens criminals, making them a threat to public safety.

Thus, the law was born out of opportunistically appropriating a tragedy. In 1992, a parolee and repeat violent offender murdered young Kimberly Reynolds, the daughter of Mike Reynolds. Reynolds sought revenge for her death, by organizing judges, law enforcement and lawyers to create a law that would "incapacitate" repeat offenders like his daughter's killer (McCarthy, 1994). The group devised a proposal called "The Street Sweeper" because it was as Reynolds put it, "designed to get all criminal garbage off the streets" (Page, 2011, p. 11). Under the law, individuals with a record of one "serious" or "violent" offense who committed any additional felony would receive a sentence twice as long as the current offense. Additionally, the individual would have to serve 80 per cent of his prison sentence before he would be eligible for release. The third-strike enhancement is reserved for those offenders with two prior convictions for "serious" or "violent" crimes and a third conviction for any felony. Third-strikers would receive a life term and would be ineligible for parole until they served 100 per cent of the 25year sentence. The proposal even stipulated that nonviolent and non-serious offenses would count as a second and third strike (Page, 2011, p. 117).

Critics of the proposal believed the law was too sweeping because the triggering offense did not have to be violent or serious, but throughout the campaign for three strikes, Reynolds and his supporters avidly worked to transform their proposal into law. Reynolds enlisted legislators Bill Jones (R-Fresno) and Jim Costa (D-Fresno) to introduce the bill to the legislature as Assembly Bill 971 (AB971). The bill failed to secure a consensus to pass, and Reynolds needed 400,000 voter-registered signatures in order for the bill to qualify for the ballot, but he lacked the funding to pay for it. Hope 
arrived when he received $\$ 40,000$ from the National Rifle Association, a conservative lobbyist group that supports 'tough-on-crime' measures, like the Three Strikes Law. Nevertheless, the contribution still was not enough to finance a statewide signature gathering campaign (Page, 2011, p. 118).

The following year, on October 1, 1993, a tragedy occurred that changed Reynolds's campaign prospects. 12-year-old Polly Klass was kidnapped from her home and murdered in Petaluma, California, by Richard Allen Davis, a repeat violent offender (a repeat violent offender also killed Reynolds' daughter). Davis had been released from prison for three months when he committed this murder. He recently served eight years of a sixteenyear sentence because he had earned good-time and work-time credits that made him eligible for an early release. Davis's crime created a public outcry on conservative radio shows, which criticized lawmakers for failing to pass AB 971 and asked their audiences to target their anger towards repeat offenders and politicians with no spine who were 'soft-on-crime'.

The national media appeared on the scene, calling Polly Klass "America's Child". Before Polly Klass's death, Reynolds managed to accumulate 20,000 of the 385,000 signatures required to place his initiative on the November 1994 ballot. After law enforcement discovered Polly's body, Reynolds' campaign accumulated an additional 300,000 signatures. Reynolds received extra support from the Klass family. However, once the Klass family, Joe and Mark, discovered Reynolds's bill allowed both nonviolent and non-serious offenses to trigger a life sentence, both men pulled their support, but Mark Klass later re-joined the campaign (Page, 2011, p. 119). In addition to receiving the Klass's support, the National Rifle Association added an additional $\$ 60,000$ to their earlier contributions of $\$ 40,000$, and a wealthy Republican Congressman named Michael Huffington, who in 1994 was running against Democratic Senator Dianne Feinstein for her seat, contributed $\$ 350,000$ to the Reynolds's statement that human garbage is a racial connotation alluding to life's unfortunate people, which on the streets is minorities. Reynolds would eventually situate Huffington as co-chair of his campaign. Apparently, Huffington's move of contributing and endorsing Reynolds's law was a strategy to unseat Senator Feinstein. Then, the president of the CCPOA, Don Novey, and his union contributed $\$ 100,000$ to the Three Strikes campaign (Page, 2011, p. 119).

As Zimring et al. (2001) discovered, CCPOA members contributed $\$ 100,000$ to Reynolds's campaign, because they knew there would be a 
direct correlation between the enactment of the Three Strikes Law and the expansion of the prison industry, resulting in hiring prison staff, union dues, overtime, and the ability to negotiate contracts beneficial to them. Studies have shown those states with large and influential guard unions, like the CCPOA, have large prison populations. In the CCPOA magazine, Peacekeeper, Novey asked his union members to rally behind three strikes and help gather signatures. He argued:

I suggest to you, my fellow correctional officers, that we deliver a Christmas present to the people of California in the form of an initiative. We now have an opportunity to put societal thugs behind bars to stay, whether for violent or serious crimes. Correctional Peace Officers now have that rare chance to give California citizens a break. Please get behind California's "Three Strikes and You're Out" initiative (Page, 2011, p. 120).

Many California Republicans endorsed AB 971. Of the five bills floating in the legislature regarding repeat offenders, Reynolds's version stood out as the most draconian. Republican Governor Pete Wilson, who was running against Democratic opponent Kathleen Brown for re-election, endorsed Reynolds's bill over the other four bills. Republicans in both houses did the same, with no oppositions from Democrats, because those Republicans knew that 80 per cent of the public supported AB 971 (Page, 2011, p. 120).

Finally, in 1994, the state legislature passed AB 971, relieving Reynolds of having to go the ballot initiative route. Yet, Reynolds went the initiative route anyway to prevent politicians from tampering with the bill unless they got a two-thirds vote in the legislature to amend it. After being asked why he submitted signatures for Proposition 184 after the legislature passed a champion bill, Reynolds responded, "We want this puppy screwed, glued and tattooed" (Page, 2011, p. 120). Thereafter, the people of California (not knowing the proposition included nonviolent and non-serious offenses) voted Proposition 184 into law, on November 7, 1994.

Clearly, based upon the historical context of the information provided herein, politics and revenge had a part to play in three strikes becoming law. At the outset, the special interest groups (i.e., CCPOA, Mike Reynolds, victim rights groups, and conservative politicians) had a vested interest in three strikes becoming law: one, conservatives got retribution over liberal policies and politicians who enacted lenient sentences for repeat offenders; 
and two, conservatives and special interests groups used the law to position themselves to fill the prisons, use taxpayers' money to build more facilities, increase their memberships and dues to profit financially, and get elected to a political office.

Thus far, this striking-report has concentrated on the historical background, showing the circumstances that brought together the related social and political groups to create and enact the Three Strikes Law. Again, drawing on Page (2011), as well as others, the next section concentrates on the law's language, showing its relationship to the circumstances in which the law was created. Then the focus shifts to the law's application, which has sent over 80,000 second strikers, and 7,500 third-strikers to state prison (Primer, 2005).

As previously noted within the historical context of the Three Strikes Law, the law is applied to individuals who have been convicted of one serious or violent offense and any additional felony after the initial conviction. Those offenders receive a sentence twice as long as the most recent offense, and are mandated to serve 80 per cent of their sentence before they become eligible for parole. The third strike enhancement is reserved for those offenders with two prior convictions for serious and violent crimes and a third for any felony, regardless of its non-seriousness. Third-strikers receive a life term and are ineligible for parole until they serve 100 per cent of the minimum term of their penalty (Page, 2011, p. 117).

Some nonviolent and non-serious offenses are counted as a second or third strike. For example, for a second serious offense, the length of sentence is double the years normally associated with that second offense. That offender is ineligible for parole until 80 per cent of the double time is served. An individual with a prior first-degree burglary conviction can receive 32 years for his second serious offense (say robbery), but the crime carries a 16-year sentence before the Three Strikes Law is applied. The law can even raise a misdemeanour to a felony. Specifically, an individual with two prior robbery convictions can receive 25 years to life for his third nonviolent or non-serious conviction. That is, a misdemeanour petty theft can be raised to a felony, resulting in a third strike conviction because of the prior theft-related robberies. Furthermore, first and second-strike prior felony conviction enhancements are retroactive to juvenile convictions. To illustrate, third-striker Isaac Ramirez was convicted in 1996 for petty theft with priors for stealing a VCR from a Sears department store. His two priors 
were theft from a Lucky store and theft of television from Kmart in 1992. He served six-months for the thefts. Four years later, he was sentenced to life in prison for his third theft (for other aspects of the laws application see Primer, 2005, pp. 1-5).

The application of the law to nonviolent and non-serious offenses is a distortion of the original intent of the law. The original intent was to keep the public safe from repeat serious and violent offenders like the people who murdered Kimberly Reynolds and Polly Klass. Those criminals symbolized the ultimate depravity and lawlessness. Their cases paved the road for advocates in favour of the Three Strikes Law to deceive voters about how the law would be applied and led to the law's passage through the general election ballot.

Since the enactment of the Three Strike law, several challenges have been made over the past 18 years in the state and federal courts arguing against its implementation and constitutionality. In People v. Superior Court (1996) a challenge was raised, asking whether a trial court judge should have the discretion to reduce a life sentence under the law by dismissing one or both of a defendant's prior convictions. Following the challenge, on June 6, 1996, the California State Supreme Court ruled that a trial judge could dismiss a prior felony conviction in the furtherance of justice. Another challenge was made to the law the following year. In People v. Furman (1997), Furman argued that two prior felony convictions tried in one court proceeding should count as one prior strike. However, the state Supreme Court ruled in 1997 that both priors do not have to be "brought and tried separately" in order to count as separate strikes. In 2003, an argument was made before the United States Supreme Court in Ewing v. California, 538 U.S. 11 (2003), that the application of a 25-years to life sentence to a nonviolent or non-serious offense under the California's Three Strikes Law violates the U.S. 8th Amendment ban on cruel and unusual punishment. The U.S. Supreme Court ruled that same year, in a 5-4 decision, that the law's application of a life sentence to a nonviolent or non-serious offense does not violate the 8th Amendment ban. The court agreed with the law's rationale to incarcerate repeat offenders for an extended period of time, and concluded that "policy decisions are for lawmakers to make, and not courts".

Interestingly, the California and United States Supreme Court's majorities on the bench are conservative judges. There are six Republicans and one Democrat on the California State Supreme Court, and five Republicans and 
four Democrats on the United States Supreme Court. These are judges as well as career politicians, whose political ideology influences their rulings on three strikes issues.

In addition to the court challenges to the Three Strikes Law, several legislative challenges have also been made between 1995 and 2003. Liberal lawmakers have repeatedly tried to amend the law and bring it back to its original intent by applying the law to serious and violent offenders (Page, 2011, p. 122). Every bill in that period failed due to effective lobbying efforts by the law's defenders: the CCPOA, conservative legislators, Mike Reynolds, and victim rights groups. The CCPOA, along with other groups that opposed three strikes reformation, successfully defeated bills that would have amended the law by financially and politically supporting those legislators who would be opposed to amending the law. Former Democratic assemblywomen Jackie Goldberg, who during her term unsuccessfully introduced three bills in the legislature, witnessed these tactics used by the law's defenders:

The people who want to keep [three strikes] are extremely well organized and make major contributions to elected officials. So what has happened is you have an enormous amount of [political] intimidation. People who are in assembly races know that they're term limited [to two-terms], know that they may want to run in a Senate Race a few years from now, and know that certain groups like police and prison guard unions, district attorneys, and crime victims organizations will pay for [or against] campaigning (Page, 2011, p. 122).

Goldberg and other politicians who favoured amending the law realized the political clout these stakeholders wielded in the legislature. Even if an amendment garnered the two-thirds vote required, the law would still need the governor's signature. Every governor since the three strikes enactment until the present day supports the law in its existing state.

Efforts to amend the law continue and still face severe opposition in the legislature. Assembly Bill 327 (AB 327) was introduced in the California Legislature on January 30, 2012 and it requires that the third strike be a violent or serious offense to trigger a life sentence. AB 327, sponsored by Mike Davis, was defeated by Republican legislatures, but Davis resubmitted the measure the following day for the 2014 general election ballot. By a 
vote of 41-33, the bill passed in the state assembly on Wednesday, January 31,2012 . The bill now heads to the senate floor for a second vote before going to the governor for his approval to have it placed on the ballot for November 2014.

The law's supporters defeated a 2004 Ballot Initiative to amend the law. Proposition 66 (Prop 66) proposed that the third strike be a violent or serious offense, and redefined certain felonies as non-strikes. Jim Benson and Sam Clauder, two men who originally supported three strikes, spearheaded Proposition 66. Benson and Clauder worked with the 2000 Proposition 36 campaign. This proposition was a successful drug diversion that sent nonviolent drug addicts to treatment, instead of state prison. Even offenders who would have faced a third-strike for drug possession, could escape a life sentence and be diverted to a drug treatment facility.

For Prop 66, Benson and Clauder sought the help of Joe Klass, father of Polly Klass, to assist them in raising funds. They launched a letter and e-mail campaign to raise money using the endorsements of Joe Klass, and actor Ed Asner. They surprisingly received $\$ 300,000$ from an insurance tycoon, Jerry Keenan of Sacramento, California, whose son was sentenced under the law as a second-striker for two counts of vehicular manslaughter and one count of "causing great bodily injury". Two passengers were severely injured as a result of his son's drunk driving (Page, 2011, pp. 123-124).

Opposition to Prop 66 (e.g. CCPOA, Mike Reynolds, JHV, and other political and law enforcement officials) opposed changing the definition of certain violent or serious crimes, which allowed those who were sentenced under the law for those offenses to be resentenced to a non-life term. They used Keenan's son's crime of "causing great bodily injury" as a strategic argument to the public that Keenan's motive for changing the law was to get his son out of prison (Page, 2011, p. 124). The CCPOA organized an elite coalition of law enforcement groups to defeat Prop 66. A month before the general election, the CCPOA spent $\$ 245,650$ on the "No on 66" campaign. After the CCPOA and other donors successfully raised a considerable amount of funds, they released this false statement to the public through spokesperson and president of the California Police Chiefs Association, Cam Sanchez. Sanchez argued:

Every day between now and the election, we'll be releasing at least one mug shot and rap sheet of a felon who will be released early by Proposition $66 .$. These are very dangerous people-serial child molesters, 
rapists, murders, [sic] and career criminals with long histories of serious crime... They and thousands more like them will be back on the streets if Proposition 66 becomes law (Page, 2011, p.126).

Despite the misleading campaign propaganda, polls showed an overwhelming 65 per cent of the public expressing approval for the proposition. The proposition's language was twisted and grossly misrepresented the category of people the bill would give relief to. The opposition's deceptive scare tactics informed the public that "child molesters, rapists, and murderers" would be released. Individuals who were convicted of a nonviolent or non-serious third strike but had a prior conviction for "child molestation, rape, or murder" qualified to be resentenced (Page, 2011, pp. 130-131).

With victory looking likely for proponents of Proposition 66, the opposition received a large contribution from Orange County billionaire, Henry T. Nicholas III, chief executive officer of Broadcam Corporation. He gave $\$ 1.9$ million to the "No on 66 " campaign, and $\$ 1.6$ million subsequently for a total of $\$ 3.5$ million. Many speculated that his contribution was motivated by the 1983 murder of his sister. Nicholas's mother, Marcella Nicholas Leach, co-founded the group Justice for Homicide Victims (JHV) as a result of her daughter's murder and ultimately became co-chair of JHV. After receiving the U.S. Department of Justice's National Crime Victims' Right Week Award in 2005, the media portrayed Mr. Nicholas as a saviour on the behalf of victims, instead of a wealthy businessman associated with JHV and CCPOA.

The "No on 66" campaign received support from former governors Pete Wilson and Arnold Schwarzenegger after Nicholas gave a large cash contribution. Governor Schwarzenegger played the leading role to defeat Prop 66 by using his popularity and making commercials. Schwarzenegger spoke into the camera saying, "Under Proposition 66, 26,000 dangerous criminals will be released from prison. Child molesters, rapists, and murderers. Keep them off the streets and out of your neighborhood. Vote no on 66. Keep them behind bars" (Page, 2011, pp. 126-128). A background picture showed twenty mug shots of rugged-looking prisoners as he spoke against the proposition.

Some politicians who were originally against the Three Strikes Law currently support it. One prominent example is Governor Jerry Brown, who campaigned against Prop 66 at the behest of his former foe, the CCPOA. 
To thank Brown for his help, the CCPOA financially supported his 2010 governor's race. Currently, Brown continues to maintain strong ties with the CCPOA (Page, 2011, pp. 128-129).

Through the use of deceptive tactics and bestial description of prisoners who qualified for sentencing relief, along with the line-up of authoritarian figures who opposed the proposition, the opposition succeeded in defeating Prop 66 by 47.3 to 57.7 per cent (Page, 2011, pp. 130- 131). The actions taken by the law's supporters demonstrate the desperate measures they took to preserve the Three Strikes Law, including violating the law by misleading the public to further their agenda.

The next and fourth section of this striking-report focuses on the law's impact on society. First, the focus aims at whether or not the law has deterred criminal behaviour. Second, the focus shifts to the argument of critics who point out the law's discriminatory application, and third, the costs to taxpayers. As will be shown, the law has had an adverse effect in all of these areas. The law exists as a costly, ineffective and an unusually discriminatory piece of legislation.

Established through the historical background of this striking-report, Mike Reynolds, the primary architect of the Three Strikes Law, named the law The Street Sweeper because he believed the law "would sweep all the human garbage off the street" (Page, 2011, pg. 11). Evidently, he believed the law would significantly reduce crime. However, studies done by the Legislative Analyst Office (LOA) and other economists find insignificant deterrent effects of the Three Strikes Law over the past decade. While crime statistics declined during the period following the passage of the law, this decline was part of a national decline caused by many factors. In fact, studies done by LAO analysts found crime rates declining by 10 per cent ten years prior to the law's enactment, and continuing to decline by 43 per cent between 1994 and 1999. In 1999, crime rose by 11 per cent. The violent crime rate fell 8 per cent during that same period, and continued to decline, for an overall reduction of 43 per cent between 1994 and 2003 (Primer, 2005, p.12). These statistics were used misleadingly by Three Strikes proponents to claim the law had a deterrent effect, but actually these statistics were part of a national trend of declining crime rates during that time. National crime rates reported by the Federal Bureau of Investigation's Uniform Crime Report acknowledged that crime dropped 31 per cent between 1991 and 2003, with violent crime down 37 per cent over that time 
(Primer, 2005, p. 12). Scientists also found other factors outside the law, which contributed to a reduction in crime, such as a strong economy, more effective law enforcement practices, demographic changes, and a decline in handgun use (Primer, 2005, p. 12).

Throughout California, county-by-county studies have shown drops in crime rates in counties that aggressively and leniently enforce the law. The largest crime reduction was reported at 45 per cent, and the lowest at 44 per cent, showing only a 1 per cent discrepancy to be based on whether or not the law was enforced. Kern, Los Angeles, San Diego, and Riverside counties had the highest three strikes conviction rate but saw a drop in crime rates between 1994 and 2003 by 37 per cent, whereas Ventura, Contra Costa, Alameda, and San Francisco counties had lower conviction rate of 33 per cent but still saw a drop in crime over the same period (Primer, 2005, p. 13). The county-by-county study and national trend assessment demonstrated that other probable factors outside the Three Strikes Law being enforced that was responsible for a decline in crime for California.

As mentioned earlier, Mike Reynolds stated that the Three Strikes Law is designed to "sweep all the human garbage of off the streets". He alluded to his belief that the law would effectively reduce crime. Reynolds's language included two derogatory connotations, implying that marginalized people, who are predominately minorities, are "human garbage". These are the people Reynolds alluded to when making the statement about "human garbage". In fact, during the campaign for the Three Strike law in 1994, the Los Angeles Times reported proponents of the law using "highly negative images of offenders, [and making] derogatory public comments about repeat felons as subhuman "three-time losers", "human debris", [who are] animals best kept in cages" (Dzur, 2010, p. 359).

A December 2004 Legislative Analyst Office Report, shows that African Americans account for the largest second- and third-striker populations under the Three Strikes Law. African Americans make up 45 per cent of the thirdstriker population, followed by Hispanics at 33 per cent, and whites at 26 per cent (Primer, 2010, p. 10). In another study conducted by the Los Angeles Sentinel, writer Kevin Herrera shows, "how the law exacerbated the racial disparities in the prison population, with African Americans making up 31\% of the prison population and only $7.5 \%$ of the state population" (Herrera, 2001). Additionally, Stephen Vagmen, Los Angeles civil rights attorney, said that Three Strikes is another form of racial profiling. He explained: 
"Society does not wish to deal with a black and Latino underclass that it has created through its economic system. Racial profiling is basically the first step of the Three Strikes Law. It's designed to take people of color off the streets and keep them out of white neighborhoods. And the Three Strikes Law is designed to keep people of color out of society, and put them in prison" (Parker, 1999).

Some people agree with Vagmen's position. They could argue that the law's application is not blind to race. The law is not about equality in sentencing but about removing African Americans from the streets. This displacement disenfranchises them and exacerbates societal problems within their family structure, which denies them opportunities because of their felony status. They are unable to vote. They have little or no economic and education input. They have little or no entrepreneurial activity. Very few of these pariahs own real estate. And, targeting the black underclass through the law separates families, which creates one-parent households.

Any law with this bias in application would be a problem, but it is a nightmare when it also hamstrings California's economy. In 1994, economists believed the Three Strikes Law would be costly to taxpayers, creating prison operation costs in the billions of dollars by the year 2003, and up to billions of dollars yearly by 2006 (Primer, 2005, p. 10). According to the California Legislative Analyst Office, prison construction is anticipated to cost a staggering $\$ 20$ billion by 2026 . Although these predictions are exaggerated, the law nevertheless has had, and will continue to have, a significant impact on state spending. California taxpayers spend $\$ 49,000$ to incarcerate each prisoner yearly, with over 40,000 people imprisoned under the Three Strikes Law, according to the LAO, which adds up to nearly \$2 billion a year in costs for the state of California (Primer, 2005, p. 10).

Costly litigation against the state has also increased. Second- and thirdstrikers take civil action against the state by challenging the length of their sentences and the living conditions they face due to prison overcrowding. All legal proceedings are paid for with taxpayers' dollars. As this strikingreport highlighted earlier, two- and three-strikers must serve the majority of their term before they are eligible for parole. Prisoners spent an average of 21 months in prison prior to the Three Strikes Law, but by 2004 this average increased to 25 months. This increase is due partly to second strikers who were paroled in 2004, serving 43 months in prison and costing the state 
$\$ 60,000$ per second striker. Furthermore, third-strikers are also serving longer sentences than they would have prior to the law's enactment. This fact is true for nonviolent and non-serious offenders. Third-strikers must appear before the Board of Parole Hearings to be released because of their life sentence. As of 2012, no lifer has appeared before the board and the earliest any third-striker will be eligible to appear before the board will be 2019. Consequently, the length of time to be served in these two- and three-strike sentences creates an aging prisoner population, which increases the cost of health care and transportation costs to medical facilities for ill prisoners (Primer, 2005, p. 10). Nonviolent third-strikers are expected to cost the state almost $\$ 200$ million a year for the next 25 years, according to the state auditor (Kaplan, 2012).

With such high costs for prison stays, the State of California could save millions of dollars annually by reforming the Three Strikes Law. The opportunity for three strikes reformation might present itself again with the potential ballot measure coming in November 2012. If voters approve the initiative, backers believe that about 3,000 of the 4,000 incarcerated nonviolent third-strikers serving time in state prisons could be eligible for resentencing. Reforming the law could save the state $\$ 150$ million to $\$ 200$ million a year (Lagos, 2012).

In summation, the law has had a significant effect on California's prison system. A third of California's prison population is serving enhanced sentences under the Three Strikes Law. Statistics from the LOA has been used to conclude that there is no evidence to establish that the law has contributed to California's decreasing crime rate; nonetheless, the law continues to increase prison spending and the state's budget deficit. The state should abolish the practice of giving life sentences to people who commit minor crimes, especially at a time when California's citizens feel the buckling effects of a recession that creates school closures, increases tuition fees, loss of jobs and other social services that are vital to personal and social prosperity.

Additionally, because of the prison overcrowding, the state faces a federal court order to reduce its prison population. Certainly, the Three Strikes Law is a public policy issue that can be resolved by California's elected officials, but cannot be easily addressed because of the politics described in this striking-report. California's elected officials improperly represent their constituents by enacting laws that give life sentences to petty offenders and 
therefore exacerbate current economic problems. Washington and other states have amended their Three Strikes Laws. ${ }^{2}$ California could model its law after Washington's law. As the state faces a budget shortfall that continually devastates education, health care, and human services programs, unnecessary spending on incarceration is nothing less than fiscal mismanagement.

Therefore, this striking-report is an appeal to California voters to cast their ballots during the 2012 ballot initiative process in favour of reforming the Three Strikes Law. Voters can reinstate the budget constraints that contributed to Washington amending its Three Strikes Law, as well as the "spirit of the law", by voting for it to be amended and only applied to serious and violent offenses. Reform will also end a very expensive battle between proponents and opponents of the law. Ultimately, instead of spending millions of dollars to warehouse nonviolent or non-serious offenders, for decades, under the Three Strikes Law in its current form, reformative policy has the potential to usher California to a revitalized economy that spends more tax-dollars on education, health care, and public safety. ${ }^{3}$

\section{ENDNOTES}

* Note from the issue editors: In November 2012, California voters passed Proposition 36 , which affected some 4,000 prisoners who were serving 25-to-life sentences for nonviolent offences. With the passage of this law, life sentences will be imposed only if the third strike was for a felony offence. As a result, nonviolent prisoners are now able to petition for relief in the form of new sentences and release.

1 Striking-report refers to the Three Strikes Law, and how California continues the practice of striking out offenders with a history of nonviolent offenses. The title's reference also points to the report's striking information about the Strikes law that many voters and potential voters are more than likely unaware of.

2 Washington only applies its Three Strikes Law to offenders who commit serious offenses.

3 Public safety can be achieved by amending the Three Strikes Law and focusing on individuals who commit violent offenses.

\section{REFERENCES}

A Primer: Three Strikes-The Impact After More Than a Decade. (2005 October). Retrieved from http://www.lao.ca.gov/2005/3_strikes/3_strikes_102005.htm

Dzur, Albert (2010) "The Myth of Penal Populism: Democracy, Citizen Participation, and American Hyperincarceration”, Journal of Speculative Philosophy, 24(4): 354379. 
Herrera, Kevin (2001) "Study: 'Three Strikes Law' Ineffective Racially Biased", Los Angeles Sentinel - September 5. Retrieved from <http://www.highbeam.com/ doc/1P1-79459448.html $>$.

Kaplan, Tracy (2012) “Group seeks initiative to reform California's Three Strikes Law", insideBayArea.com - June.

Lagos, Marisa (2012) "2012 ballot initiative”, San Francisco Chronicle - January 31.

McCarthy, Charles (1994) "Film examines "Three Strikes", Fresno Bee, p. 2 - May 31.

Page, Joshua (2011). Toughest Beat: Politics, Punishment, and the Prison Officers Union in California, New York: Oxford University Press.

Parker, Edward (1999) "Black leaders blast Three Strikes Law", Los Angeles Sentinel - June 17.

San Jose Mercury News (2012) "Editorial: Pass Prop 36 to reform Three Strikes Law" - August 3. Retrieved from <http://www.mercurynews.com/opinion/ci_21228830/ mercury-news-editorial-pass-prop-36-reform-three>.

Tyler, Tom and Robert Boedman (1997) "Three Strikes and You're Out, But Why? The Psychology of Public Support for Punishing Rule Breakers", Law and Society Review, 31: 237-266.

Zimring, Franklin, Gordon Hawkins and Sam Kamin (2001) Punishment and Democracy: Three Strikes and You're Out in California, New York: Oxford University Press.

\section{ABOUT THE AUTHOR}

Forrest Lee Jones is incarcerated at San Quentin State Prison in California. He can be contacted at:

Forrest Lee Jones, E89706

San Quentin State Prison

Facility 1-N-61 Upper

San Quentin, California 94964

USA 